\title{
THE EFFECT OF KNOWLEDGE LEVEL (IQ) AND PHYSICAL CONDITIONS (POWER, FLEXIBILITY AND COORDINATION) ON SMASH TECHNIQUE LEARNING SKILL IN SEPAK TAKRAW
}

\author{
Jufrianis $^{1 \mathrm{ABCE}}$, Raffly Henjilito ${ }^{2 \mathrm{CDE}}$, Hernawan $^{3 \mathrm{CDE}}$, Sukiri $^{3 \mathrm{CDE}}$, \\ Abdul Sukur ${ }^{3 \mathrm{CDE}}$, Dindin Abidin ${ }^{4 \mathrm{BDE}}$, Manil Karakauki ${ }^{5 \mathrm{BDE}}$, Syed \\ Kamaruzaman Syed Ali ${ }^{5 \mathrm{BDE}}$, Kukuh Wahyudin Pratama ${ }^{6 \mathrm{ACDE}}$ \\ ${ }^{1}$ Universitas Pahlawan Tuanku Tambusai \\ ${ }^{2}$ Universitas Islam Riau \\ ${ }^{3}$ Universitas Negeri Jakarta \\ ${ }^{4}$ Universitas Islam 45 Bekasi \\ ${ }^{5}$ University of Malaya \\ ${ }^{6}$ Institute of Advanced Science, Engineering, and Education \\ Authors' Contribution: A - Study design; B - Data collection; C - Statistical analysis; D - Manuscript Preparation; E - Funds Collection
}

Corresponding Author: Jufrianis, E-mail: jufrianis@universitaspahlawan.ac.id

Accepted for Publication: September 07, 2021

Published: September 25, 2021

DOI: 10.17309/tmfv.2021.3.10

\begin{abstract}
Athlete's knowledge level (IQ) is needed to increase smash technique learning skill in sepak takraw. Besides, physical conditions which consist of power, flexibility and coordination, are also determined athlete's accomplishment in learning smash technique in sepak takraw.

The study purpose. The aim of this research was to discover the direct influence between knowledge level (IQ) and physical conditions (power, flexibility and coordination) on smash technique learning skill in sepak takraw.

Materials and Methods. The method used in this research was quantitative. Path analysis was conducted to analyze the result. As many as 50 athletes of sepak takraw from capital city of Jakarta were taken as population. Those athletes were also taken as sample by using total sampling. The sample was the athletes who joined the regional and national championship.

Results. Based on the research it was obtained: 1) knowledge level (IQ) affects smash technique learning skill in sepak takraw directly as many as $0.982 ; 2$ ) physical conditions (power, flexibility and coordination) affect smash technique learning skill in sepak takraw directly as many as 0.845 ; and 3) overall, knowledge level (IQ) and physical condition (power, flexibility and coordination) affect smash technique learning skill in sepak takraw directly as many as 0.703 .

Conclusion. Therefore, it could be concluded that knowledge level (IQ) and physical conditions (power, flexibility and coordination) affect smash technique learning skill in sepak takraw on the athletes of capital city of Jakarta. Keywords: Knowledge Level (IQ), Physical Condition, Smash Technique, Sepak Takraw.
\end{abstract}

\section{Introduction}

Sport education is one of sport science fields which supports someone to reach his desired achievement. The development of sport education is divided into three kinds

(c) Jufrianis, Henjilito, R., Hernawan, Sukiri, Sukur, A., Abidin, D., Karakauki, M., Syed Ali, S. K., Pratama, K. W., 2021. namely educational sport, recreational sport and sporting achievement. Educational sport is engaged physical education as a part of continuous and well-organized education process in order to obtain knowledge, personality, health and physical fitness. Recreational sport is kind of sport which conducted by people using their hobby and ability based on their condition and society's cultural value aimed to attain their health, fitness and happiness. Sporting achievement is kind of sport which guiding and developing athlete 
gradually and continuously through competition to obtain achievement using sport technology and science. This is in line with Indonesian Law No 3 Year 2005 about Indonesian Republic National Sport System in Paragraph 1 Verse 13 which stated, "Sporting achievement is sport which build up and develop the athlete as planned in sustainably and step by step way supporting by sport technology and science." In implementing sporting achievement, there are also social values applied such as high value of sportsmanship. One of sporting achievement branches is sepak takraw.

Hermawan, Asmawi, and Tangkudung (2019) mentioned sepak takraw was a game played in rectangle field with flat surface (both in indoor and outdoor place) as long as it is free from obstacle. This game is started with service conducted by tekong (skipper) toward opponent's area. Then, the opponent plays the ball using leg or the other body parts except hands and touches the ball no more than three times. There are so many factors supporting the play of sepak takraw. The most important factors are the mastery of individual technique in playing sepak takraw and teamwork. The more perfect each player mastering the technique, the more good the quality of game. To keep the game played well, the player must master the basic technique very well.

Padli et al. (2019) divided the ability in sepak takraw into two parts namely the individual basic technique and the ability in mastering the game. The individual basic technique consists of sepak sila, sepak cungkil, sepak badek, sepak cross, blocking, heading, using chest and shoulder. Zarei \& Ramkissoon (2021) mentioned the ability in mastering the game consists of service, give bait, smash and block. In order to get big score and win the game, the player must master smash technique very well. Smash is the player's effort in attacking opponent's area. Smash is dynamic and varied movement to get point. In doing smash, the player need optimal physical skill so that his smash technique can be more directed, faster and more accurate.

Hamid et al. (2015) stated that in performing smash, the athlete must have a complex series of movement which is supported by good physical condition component. The power of leg muscles is needed to perform good physical condition. According to Ribeiro et al. (2020) power is the product of two abilities: strength and speed. It is also known as the ability to apply the highest force in the shortest time. Unlike power lifting, in which the athlete expresses (maximum) strength without time limitation, athletes in all other sports face time constraints in applying as much force as possible. According to Hager et al. (2020) the explosive power of leg muscles was someone's leg muscles ability to jump as high as possible (explosive). If the athlete of sepak takraw has a very high jump, it would make him easier to perform good smash. Hence, in order to perform good and directed smash, the athlete must have a very good explosive power of leg muscles. Besides, to conduct good smash, the athlete needs the body flexibility.

Flexibility is an important component in human body to perform the movement as wide as possible. Therefore the stretching exercise is a necessary part in preparing further sport. The exercise in increasing muscle's flexibility is applied to avoid the injury and hypertension (miogelisis). Besides, this exercise is conducted after the power exercise program to prevent muscle contracture. In general, this effect is associated with stretching prevention to shortening muscles (Kolumbet, Natroshvili, \& Chernovsky, 2018).

Nugroho et al. (2021) stated flexibility of the human body refers to the range of movement in a joint or series of joints. Quality of life is enhanced by improving and maintaining a good range of motion in the joints. Loss of flexibility can be a predisposing factor for physical issues such as pain syndromes or balance disorders. Many factors are taken into account when establishing the flexibility of a particular human body: joint structure, ligaments, tendons, muscles, skin, tissue injury, fat tissue, body temperature, age and gender, all influence an individual's range of movements.

In accordance with the result of research journal written by Nasrulloh et al. (2021) the acute effects of static stretching on torque production were dependent on the individual's flexibility; the greater the flexibility, the lower and shorter the torque decreases. In addition, stretch-induced torque reduction recovered faster in individuals with high flexibility. So, the static stretching in torque producing depends on the individual's flexibility. When the athlete performs the huge flexibility, he experiences his torque slighter and his flexibility becomes shorter. Besides, the reduction of torque is induced faster in high flexibility athlete.

Ehlert (2020) on text book Acsm's Foundation of strength training and conditioning described flexibility is the ability of a joint to move freely its ROM. Enhanced joint flexibility can reduce injury risk, improve muscle balance and function, increase performance, improve posture, and reduce the incidence of low back pain. The best ways to increase flexibility is to perform exercises in a full ROM and engage in a proper stretching program, preferably at the end of a workout when the muscles are thoroughly warmed up. Hence, the flexibility must be trained. The characteristics of flexibility are stretching the joints and extending a muscles group. There are four types of stretching according to Rahman \& Islam (2020) namely static, dynamic, proprioceptive neuromuscular facilitation (PNF) and ballistic.

Based on the theory above, the flexibility of hip joints in this research is viewed as an important aspect. The flexibility in performing smash could be described as the ability in conducting kicking which requiring hip joints movement as wide as possible without experiencing injury. The development of flexibility could be increased by static stretching, dynamic stretching, ballistic stretching and proprioceptive neuromuscular facilitation (PNF). In performing smash, not only power and flexibility but also good coordination between eyes and legs support the athlete to carry out smash technique. This coordination is required to ensure the athlete's leg touches the ball properly which is appropriate with the basic technique of sepak takraw.

Coordination is someone's ability to combine some movement elements into one series of conformable movement and suitable to the aim. Coordination is useful for carrying out tactic and developing mental readiness (Bolotin \& Bakayev, 2018). When the athlete has good coordination, his movement efficiency would be arranged nicely. He would not feel over exhausted so that he would be able to avoid injury.

Hughes (2019) stated these findings suggest males and females adopt similar intra-limb coordination strategies when landing, however, females exhibit greater variability in coordination which may indicate greater adaptation in 
coordination patterns in an attempt to mitigate the effects of fatigue or compensate for gender differences in landing kinematics and kinetics identified in previous research.

Le et al. (2020) concluded that coordination is the ability to commit various movement in certain difficulties quickly, accurately and efficiently. Therefore, coordination states the conformable relation as a main factor happened in one movement. The reduction of coordination in daily activity starts occurring to those people over 40 years old. This condition is caused by the decrease of sensory perception and motoric response which undergoing the changes of morphology and biochemistry.

Coordination is really necessary to be mastered by the athlete of sepak takraw because when the athlete wants to perform passing, he would not see the ball. His leg must touch the ball while his eyes looking at the target. The legeyes coordination has an important role in sepak takraw. This ability is needed to control and play the ball after triggering by certain stimulus for example when the ball comes from opponent's attack. By carrying out good leg-eyes coordination the player masters the game and he is able to play the ball perfectly.

Therefore, the study purpose was to discover the direct influence between knowledge level (IQ) and physical conditions (power, flexibility and coordination) on smash technique learning skill in sepak takraw.

\section{Materials and methods}

\section{Study participants}

The population of this research was 50 athletes of sepak takraw from DKI Jakarta-Indonesia. The population was also taken as sample using total sampling (Thomson et al., 2020).

Table 1. Test detail

\begin{tabular}{llll}
\hline Item & Test & Unit & Procedure \\
\hline $\begin{array}{l}\text { Knowledge level } \\
\text { (IQ) }\end{array}$ & Questionnaire & - & Answer the question \\
\hline
\end{tabular}

The person stands side on to a wall and reaches up with the hand closest to the wall. Keeping the feet flat on the ground, the point of the fingertips is marked or recorded. This is called the standing reach. The person puts chalk on their finger tips to mark the wall at the height of their jump. The person Power Vertical Jump Centimeter (CM) then stands away from the wall, and jumps vertically as high as possible using both arms and legs to assist in projecting the body upwards. Attempt to touch the wall at the highest point of the jump. The difference in distance between the standing reach height and the jump height is the score. The best of three attempts is recorded.

The person sits with a split facing the wall. Open your legs as wide as you can to form a position as wide as possible. Hands may hold on to the floor Flexibility Wall Side Split Centimeter $(\mathrm{CM})$ to maintain balance. In such a position measure with flexomeasures or a ruler, zero on the wall. Read the difference from the wall to the crotch. Do 2 repetitions.

The person stands behind the boundary line. The person was instructed to carry out the test with the chosen foot by bouncing the ball against the wall and controlled for 60 seconds. Prior to the implementation of the test, the testes were given the opportunity to try to adapt them to the test. The test is considered successful if the kicked ball hits the target, the bouncing ball can be picked up, and bounced back to the wall. The person may not rock and catch a ball that bounces in front of the boundary line. 
Fig. 2. Flexibility test
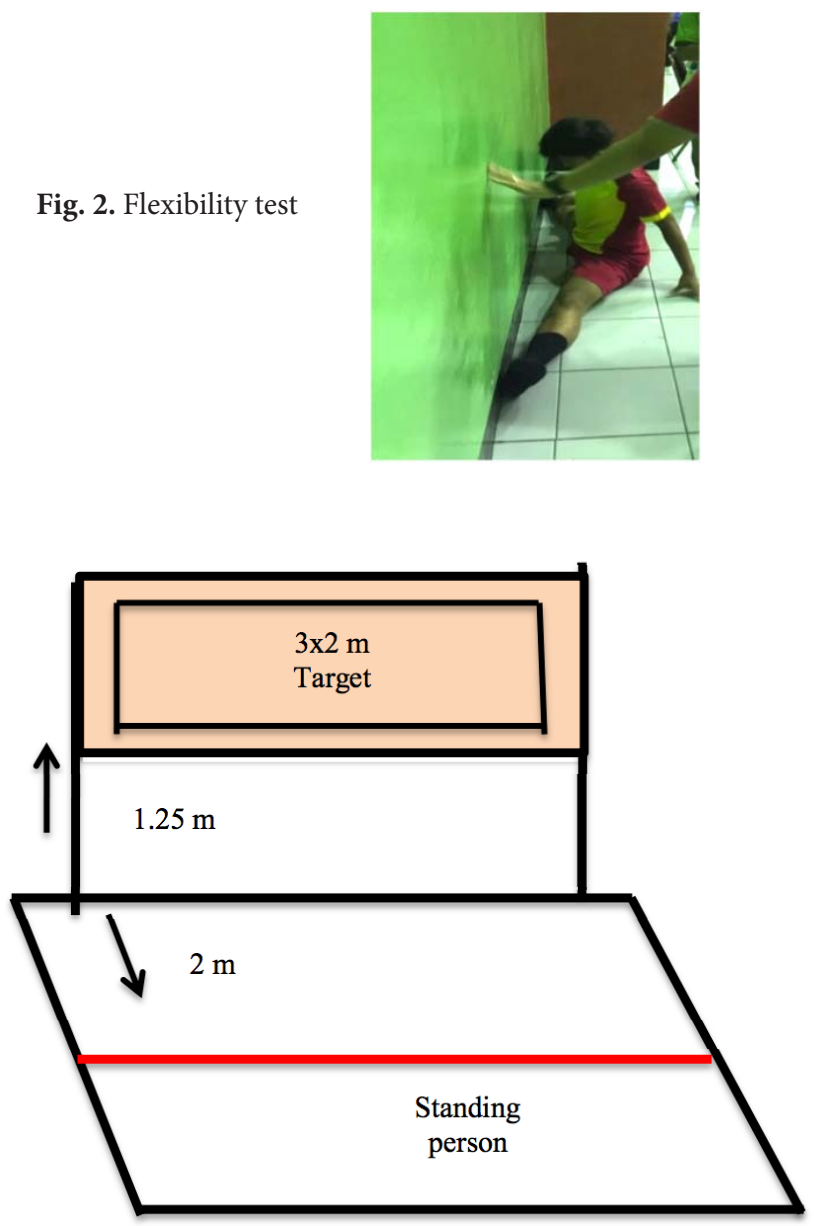

Fig. 3. Eyes-Feet Coordination Test

Meanwhile the dependent variable was smash technique learning skill in sepak takraw. The constellation model of the research method could be seen in following figure:

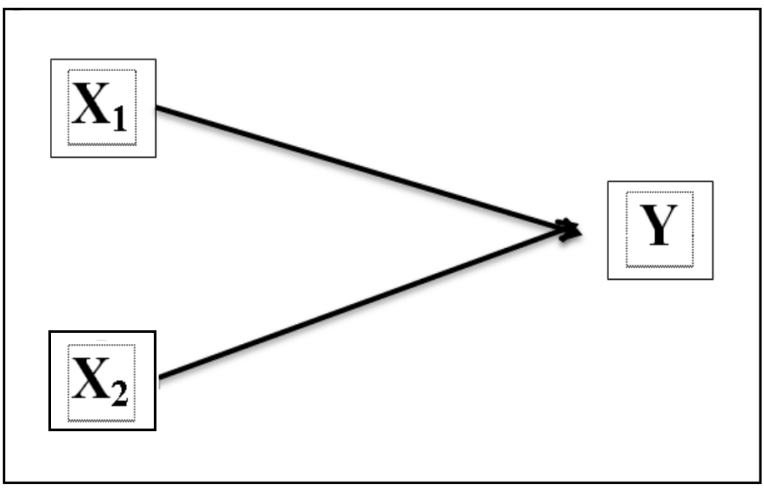

Fig. 4. The constellation of causal between variables $\mathrm{X} 1, \mathrm{X} 2$ and $\mathrm{Y}$

\section{Statistical analysis}

The method used in this research is quantitative approach using measuring and test method. The Anova path analysis was carried out to conduct the analysis technique. The path analysis studied and analyzed the relation between each research variable by measuring the direct influence in dependent variable $(\mathrm{Y})$ and independent variable $\left(\mathrm{X}_{1}\right.$ and $\left.\mathrm{X}_{2}\right)$.

\section{Results}

The result of statistical analysis indicated that the hypothesis model-1 and model-2: knowledge level, physical condition (power, flexibility and coordination) affected on smash learning skill in sepak takraw simultaneously.

The structure of model-1

\begin{tabular}{|c|c|c|}
\hline Knowledge Level (IQ) $\left(X_{1}\right)$ & $\rho \mathrm{x}_{1} \mathrm{X}_{2}$ & $\begin{array}{l}\text { Smash technique learning skill in } \\
\text { Sepak takraw (Y) }\end{array}$ \\
\hline
\end{tabular}

Fig. 5. The structural hypothesis of model-1

The result of significance testing is in following table:

Table 2. Model-1 Summary

\begin{tabular}{ccccc}
\hline Model & $\mathbf{R}$ & R Square & Adjusted R Square & $\begin{array}{c}\text { Std. Error of the } \\
\text { Estimate }\end{array}$ \\
\hline 1 & $.185 \mathrm{a}$ & .065 & .001 & 9.765 \\
\hline a. Predictors: (Constant), Knowledge Level (IQ)
\end{tabular}

Based on the coefficient of determination for model-1 $\left(\mathrm{R}^{2}\right)$ as many as 0.065 . It means as many as $6.5 \%$ of the knowledge level (IQ) variability is able to describe by smash technique learning skill in sepak takraw. Therefore, $\varepsilon=\sqrt{ } 1-$ $\mathrm{R}^{2}=\sqrt{ } 1-0.065=0.935$.

Table 3. Model-1 ANOVA ${ }^{\mathrm{b}}$

\begin{tabular}{lllllll}
\multicolumn{6}{c}{ ANOVA $^{\text {a }}$} \\
\hline Model & Sum of Squares & df & $\begin{array}{c}\text { Mean } \\
\text { Square }\end{array}$ & F & Sig. \\
\hline & Regression & 182.001 & 1 & 90.061 & 1.061 & $.061^{\text {b }}$ \\
1 & Residual & 2245.120 & 50 & 89.543 & & \\
& Total & 2199.000 & 49 & & & \\
\hline a. Dependent Variable: knowledge level (IQ) \\
b. Predictors: (Constant), smash technique learning skill in sepak takraw
\end{tabular}

According to the result of analysis from the table above, it was obtained $1, \mathrm{Fo}=1.001 ; \mathrm{db} 1=1 \mathrm{db} 2=50, \mathrm{p}$-value $=$ $0.061<0.05$. It means $\mathrm{H}_{0}$ is rejected. Hence, the knowledge level (IQ) affects smash learning skill technique in sepak takraw simultaneously.

The positive influence could be seen in following output:

Table 4. Model-1Coefficients ${ }^{\mathrm{a}}$

\begin{tabular}{|c|c|c|c|c|c|}
\hline \multicolumn{6}{|c|}{ Coefficients $^{\mathrm{a}}$} \\
\hline \multirow[t]{2}{*}{ Model } & \multicolumn{2}{|c|}{$\begin{array}{c}\text { Unstandardized } \\
\text { Coefficients }\end{array}$} & \multirow{2}{*}{$\frac{\begin{array}{c}\text { Standardized } \\
\text { Coefficients }\end{array}}{\text { Beta }}$} & \multirow[t]{2}{*}{$t$} & \multirow[t]{2}{*}{ Sig. } \\
\hline & B & Std. Error & & & \\
\hline (Constant) & 69.377 & 9.959 & & 6.277 & .071 \\
\hline $\begin{array}{l}1 \text { Knowledge } \\
\text { level (IQ) }\end{array}$ & .195 & .195 & .195 & 1.010 & .061 \\
\hline
\end{tabular}

By using knowledge level (IQ), it was obtained the path coefficient which is seen in standardized coefficient (Beta) column. The tested hypothesis was:

The formula of hypothesis model-1:

$\mathrm{H}_{0}: \rho \mathrm{x}_{1} \mathrm{y} \leq 0$

$\mathrm{H}_{1}: \rho \mathrm{x}_{1} \mathrm{y}>0$ 
Based on the table coefficient, it was gained data consecutively: $\rho \mathrm{x}_{1} \mathrm{x}_{2}=-0.195 ; \mathrm{t}_{0}=1.010, \mathrm{p}$-value $=$ $0.061<0.05$. It means $\mathrm{H}_{0}$ is rejected. On the other words knowledge level (IQ) affects smash learning skill technique in sepak takraw positively.

The structure of model-2

The hypothesis of model-2: physical condition (power, flexibility and coordination) affects smash technique learning skill in sepak takraw simultaneously.

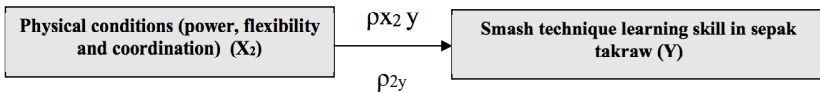

Fig. 6. The structural hypothesis of model-2

The result of significance testing is in following table:

Table 5. Model-2 Summary

\begin{tabular}{ccccc}
\hline Model & R & R Square & Adjusted R Square & $\begin{array}{c}\text { Std. Error of } \\
\text { the Estimate }\end{array}$ \\
\hline 1 & $.385^{\mathrm{a}}$ & .155 & .200 & 7.821 \\
\hline
\end{tabular}

a. Predictors: (Constant), physical conditions (power, flexibility \& coordination)

Based on the coefficient of determination for model-2 (R2) as many as 0.155 . It means as many as $15.5 \%$ of the smash technique learning skill in sepak takraw variability is able to describe by physical conditions (power, flexibility and coordination). Therefore, $\varepsilon=\sqrt{1}-\mathrm{R}^{2}=\sqrt{ } 1-0.155=0.845$.

Table 6. Model-2ANOVA

ANOVA $^{\mathrm{a}}$

\begin{tabular}{llccccc}
\hline & Model & Sum of Squares & df & Mean Square & F & Sig. \\
\hline & Regression & 620.004 & 2 & 370.087 & 4.626 & $.099^{\mathrm{b}}$ \\
1 & Residual & 2240.720 & 49 & 80.000 & & \\
& Total & 2810.244 & 48 & & & \\
\hline
\end{tabular}

a. Dependent Variable: smash technique learning skill in sepak takraw

b. Predictors: (Constant), physical conditions (power, flexibility \& coordination)

According to the result of analysis from the table above, it was obtained $1, \mathrm{Fo}=4.626$; $\mathrm{db} 1=2 \mathrm{db} 2=49$, $\mathrm{p}$-value $=0.099<$ 0.05 . It means $\mathrm{H}_{0}$ is rejected. Hence, the physical conditions (power, flexibility and coordination) affects smash learning skill technique in sepak takraw simultaneously.

The positive influence could be seen in following output:

Table 7. Model-2 Coefficients ${ }^{\mathrm{a}}$

\begin{tabular}{|c|c|c|c|c|c|}
\hline \multicolumn{6}{|c|}{ Coefficients $^{a}$} \\
\hline \multirow{2}{*}{ Model } & \multicolumn{2}{|c|}{$\begin{array}{l}\text { Unstandardized } \\
\text { Coefficients }\end{array}$} & \multirow{2}{*}{$\begin{array}{c}\begin{array}{c}\text { Standardized } \\
\text { Coefficients }\end{array} \\
\text { Beta }\end{array}$} & \multirow{2}{*}{$\mathbf{t}$} & \multirow{2}{*}{ Sig. } \\
\hline & B & $\begin{array}{l}\text { Std. } \\
\text { Error }\end{array}$ & & & \\
\hline (Constant) & 50.627 & 13.132 & & 3.855 & .001 \\
\hline Physical & .334 & .155 & .334 & 1.975 & .099 \\
\hline $\begin{array}{l}\text { (power, flexibility } \\
\text { \& coordination) }\end{array}$ & .322 & .155 & .321 & 1.901 & .078 \\
\hline
\end{tabular}

a. Dependent Variable: smash technique learning skill in sepak takraw

By using backward method, it was obtained the path coefficient which is seen in standardized coefficient (Beta) column. The tested hypothesis was:
The formula of hypothesis model-2:

$\mathrm{H} 0: \rho \mathrm{x} 2 \mathrm{y} \leq 0$

$\mathrm{H} 1: \rho \mathrm{x} 2 \mathrm{y}>0$

Based on the table coefficient, it was gained data consecutively: $\rho \mathrm{x}_{1} \mathrm{x}_{2}=-\rho \mathrm{x}_{1} \mathrm{x}_{2}=-0,155 ; \mathrm{t}_{0}=1,975, \mathrm{p}$-value $=0.099<0.05$. It means $\mathrm{H}_{0}$ is rejected. On the other words physical conditions (power, flexibility and coordination) affects smash learning skill technique in sepak takraw positively.

The structure of model-3

The hypothesis of model-3: knowledge level (IQ) and physical conditions (power, flexibility and coordination) affect smash technique learning skill in sepak takraw simultaneously.

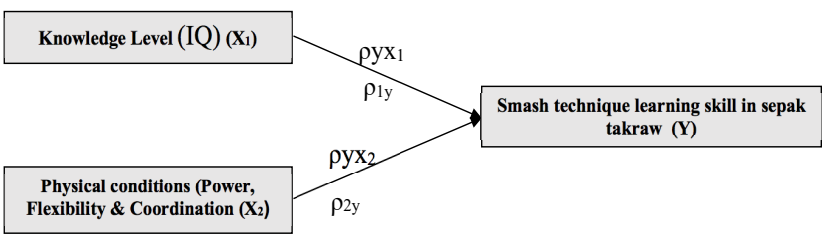

Fig. 7. The structural hypothesis of model-3

The result of significance testing is in following table:

Table 8. Model-3 Summary

\begin{tabular}{ccccc}
\hline Model & R & R Square & Adjusted R Square & $\begin{array}{l}\text { Std. Error of } \\
\text { the Estimate }\end{array}$ \\
\hline 1 & $.711^{\mathrm{a}}$ & .505 & .448 & 6.328 \\
\hline $\begin{array}{l}\text { a. Predictors: (Constant), knowledge level (IQ), physical condition (power, } \\
\text { flexibility and coordination) }\end{array}$
\end{tabular}

Based on the coefficient of determination for model-3 $\left(\mathrm{R}^{2}\right)$ as many as 0.505 . It means as many as $50.5 \%$ of the smash technique learning skill in sepak takraw variability is able to describe by knowledge level (IQ) and physical conditions (power, flexibility and coordination). Therefore, $\varepsilon=\sqrt{ } 1-\mathrm{R}^{2}=\sqrt{ } 1-0.505=0.703$.

Table 9. Model-3 ANOVA ${ }^{\mathrm{b}}$

ANOVA $^{\mathrm{a}}$

\begin{tabular}{llccrcc}
\hline \multirow{2}{*}{ Model } & Sum of Squares & df & $\begin{array}{c}\text { Mean } \\
\text { Square }\end{array}$ & F & Sig. \\
\hline \multirow{3}{*}{1} & Regression & 1063.823 & 3 & 354.608 & 8.854 & $.000^{\mathrm{b}}$ \\
& Residual & 1041.262 & 26 & 40.049 & & \\
& Total & 2105.085 & 29 & & & \\
\hline
\end{tabular}

a. Dependent Variable: smash technique learning skill in sepak takraw b. Predictors: (Constant), knowledge level (IQ), physical condition (Power, Flexibility \& Coordination)

According to the result of analysis from the table above, it was obtained $1, \mathrm{Fo}=8.854 ; \mathrm{db} 1=3 \mathrm{db} 2=26$, $\mathrm{p}$-value $=$ $0.000<0.05$. It means $\mathrm{H}_{0}$ is rejected. Hence, the knowledge level (IQ) and physical conditions (power, flexibility and coordination) affects smash learning skill technique in sepak takraw simultaneously.

\section{Discussion}

This research discover the direct influence of knowledge level (IQ) and physical conditon (power, flexibility and 
coordination) towards smash technique learning skill in Sepak Takraw. It can be shown that the result of this reseach was obtained $1, \mathrm{Fo}=8.854 ; \mathrm{db} 1=3 \mathrm{db} 2=26, \mathrm{p}$-value $=$ $0.000<0.05$. It means $\mathrm{H}_{0}$ is rejected. Hence, the knowledge level (IQ) and physical conditions (power, flexibility and coordination) affects smash learning skill technique in sepak takraw simultaneously. Therefore, beside having good physical condition, an athlete needs to have good knomledge level (IQ) to maximize the peak performance.

Relevant research previously conducted by Hidayat et al. (2020) Dominant Physical Factors Determining Takraw Playing Skills. This study aims to determine the dominant physical factors that can support the skills of playing sepak takraw which consist of serving, passing and smash. The results of this study are the dominant factor that influences service skills is coordination with a correlation value of 0.937, in baiting skills the dominant factor that affects is coordination with a correlation value of 0.933 , and the dominant factor that affects smash skills is strength with a correlation value of 0.603 .

Another relevant research previously by Ramadhan and Bulqini (2018) with the title Receive Analysis in the Final Sepak Takraw Match. This study aims to determine the relationship between Kinesthetic Perception and Sila Kicks in the Sepak Takraw Game. The results showed that there was a relationship between kinesthetic perception and the skill of Sila kicks in the strong category of sepak takraw, which was indicated by $\left(r^{2}\right)=60.90 \%$. The better the student's kinesthetic perception, the higher the ability of its sila kicks. The conclusion is that there is a close relationship between kinesthetic perception and sila kicks in the game of sepak takraw.

The most recent previous and relevant research is Wahyudi, Budiman, and Saepudin (2018). With the title Application of the TGT Type Cooperative Learning Model in the Learning of the Takraw-Oriented Big Ball Game to Improve Cooperation and Playing Skills. The purpose of this study was to determine the impact of the application of the TGT type cooperative model on playing skills and cooperation in takraw-oriented big ball learning. The results of the analysis of playing skills showed an increase in the percentage from the initial observation $(15.55 \%)$ to the second cycle test of action II (75.83\%). The cooperation test showed an increase in the percentage from the initial observation $(24.44 \%)$ to the second cycle test of action II (75.56\%). So it can be concluded that the application of the TGT type of cooperative learning model in soccer learning oriented to the takraw game can improve playing skills and cooperation in sepak takraw.

(1) In specific, the ability to respond towards specific stimulation. This ability does not need the manipulation of symbol, problem solver and rule decision; (2) The intellectual ability is the ability in interpreting concept and sign. The learning evaluation is a process in collecting information. The intellectual ability consists of categorizing ability, the analysis-synthesis ability of conceptual fact and the development of science principle. The intellectual ability is the ability in conducting cognitive activity in specific characteristic; (3) Cognitive strategy is the ability in distributing and directing its cognitive activity. This ability consists of concept and principle in problem solving; (4) Motoric ability in the ability in conducting a series of physical movement in coordination until the automatism of physical movement is created (Van Biesen et al., 2021).

Attitude was the ability in accepting and refusing the object based on its assessment. This ability transforms the assessment into standard behavior (Agus Suprijono, 2015). According to those explanations learning can be described as the process of exploring knowledge in understanding something unfamiliar through the process of studying. This process can be applied into human life to change someone's mindset, acting and behavior. According Dimiyanti dan Mudjiono (2012) knowledge was the result of discovering something new. This is obtained when someone is doing sensing on certain object. Jujun Huda Miftahul (2012) defined knowledge as what is known about certain object including science. Based on Chen et al. (2018) science was human's ability in comprehending an encountered object towards specific matter. This comprehension could be said as the result of human's effort in understanding something. Chen and Xiao (2017) divided knowledge into two types: a) scientific knowledge and b) non-scientific knowledge. Scientific knowledge is the result of someone's comprehension that is obtained using scientific method. Meanwhile, non-scientific knowledge is obtained through certain ways other than scientific method.

Based on the descriptions above knowledge could be gained through curiosity about certain object and it is obtained without using scientific method. Also, knowledge could be acquired through the experience of sensing. In learning sepak takraw technique, scientific knowledge and non-scientific knowledge are needed because it requires good physical conditions such as power, flexibility and the coordination of leg and eyes. IQ and physical condition are very influential on the smash learning skill technique. Physical condition is one of the indispensable requirements in an effort to increase one's achievement, it can even be said to be a basic need. According to Casadio et al. (2017). Physical condition preparation is one that must be considered and considered from several important cases as a necessary element in training to achieve peak performance. And with good knowledge, practice ideas, strategies in the game are easy to understand. High intelligence also has a big influence on achievement. This is in line with research conducted by Ohtani and Hisasaka (2018) shows that people with high intelligence will have better performance than people who have moderate or low intelligence.

For the future research, to improve the smash technique learning skill Researchers are expected not only to discuss IQ and physical conditions but can also be combined with (Emotional Quotient) because EQ is also one of the important aspects that athletes must possess. EQ is the ability to motivate oneself, control feelings and impulses to keep stress from turning off the ability to think, empathize and apply emotional intelligence effectively (Kurniawan and Syakur, 2017).

\section{Conclusions}

According to the result of path analysis calculation above, the hypotheses of model-1, model-2 and model-3 indicated the information about the direct influence between knowledge level (IQ) $\left(\mathrm{X}_{1}\right)$ and physical conditions (power flexibility and coordination) $\left(\mathrm{X}_{2}\right)$ on smash technique 
learning skill in sepak takraw (Y) objectively. In short, the results of the analysis could be seen in following statement:

The direct influence of $\mathrm{X}_{1}$ towards $\mathrm{Y}\left(\mathrm{X}_{1} \rightarrow \mathrm{Y}\right)$ or $\left(r_{1 y}\right)=0.155$. Therefore, the influence of knowledge level (IQ) $\left(\mathrm{X}_{1}\right)$ affects smash technique learning skill in sepak takraw (Y) as many as $\varepsilon=\sqrt{ } 1-\mathrm{R}^{2}=\sqrt{ } 1-0.491=0.982$ or $9.82 \%$.

The direct influence of $\mathrm{X}_{2}$ towards $\mathrm{Y}\left(\mathrm{X}_{2} \rightarrow \mathrm{Y}\right)$ or $\left(r_{2 y}\right)=0.604$. Therefore, the influence of physical conditions (Power, Flexibility and Coordination) $\left(\mathrm{X}_{2}\right)$ affects smash technique learning skill in sepak takraw (Y) as many as $\varepsilon=\sqrt{ } 1-\mathrm{R}^{2}=\sqrt{ } 1-0.155=0.845$ atau $8.45 \%$.

The direct influence of $\mathrm{X}_{1}$ and $\mathrm{X}_{2}$ towards $\mathrm{Y}\left(\mathrm{X}_{1}\right.$ and $\left.X_{2} \rightarrow Y\right)$ or $\left(r_{3 y}\right)=0.484$. Therefore, the influence of knowledge level (IQ) $\left(\mathrm{X}_{1}\right)$ and physical conditions (Power, Flexibility and Coordination) $\left(\mathrm{X}_{2}\right)$ affects smash technique learning skill in sepak takraw $(\mathrm{Y})$ as many as $\varepsilon=\sqrt{ } 1-\mathrm{R}^{2}=\sqrt{ } 1-0.505$ $=0.703$ atau $7.03 \%$.

\section{Acknowledgement}

Thank you to the Lembaga Pengelola Dana Pendidikan (LPDP) Republic of Indonesia for their support as a sponsor. We would also like to show our gratitude to the athletes of sepak takraw from DKI Jakarta-Indonesia for assistance with data during the course of this research.

\section{Conflict of interest}

We know of no conflicts of interest associated with this publication, and there has been no significant financial support for this work that could have influenced its outcome. As corresponding author, I confirm that the manuscript has been read and approved for submission by all the named authors.

\section{References}

Hermawan, D. B., Asmawi, M., \& Tangkudung, J. (2019). Developing machine training (DBH 2MCS) to improve beginner athlete service in Sepak Takraw in sumedang regency. Journal of Education, Health and Sport, 9(4), 42-54.

Padli, P., M, M., Zumroni, Z., \& Yulifri, Y. (2019). Training Of Basic Techniques For Sepakraw Playing For Teachers Of Penjasorkes Basic School Of Padang Utara Sub-District. Jurnal Humanities Pengabdian Kepada Masyarakat, 1(1), 24-35. https://doi.org/10.24036/jha.v1i1.8

Zarei, A., \& Ramkissoon, H. (2021). Sport Tourists' Preferred Event Attributes and Motives: A Case of Sepak Takraw, Malaysia. Journal of Hospitality \& Tourism Research, 45(7), 1188-1213. https://doi.org/10.1177/1096348020913091

Hamid, Norlizah Abdul, Abd Muzaffar Babjan, Nagoor Meera Abdullah, and Sarimah Ismail. (2015). "Anthropometric And Physiological Profiles Of Varsity Sepak Takraw Players." In Full Paper Proceeding ITMAR, 272-79. http://www.elhospital.com/temas/Una-dificilsituacion-para-el-sector-de-dispositivos-medicos-enColombia +108238

Ribeiro, J., Teixeira, L., Lemos, R., Teixeira, A. S., Moreira, V., Silva, P., \& Nakamura, F. Y. (2020). Effects of plyometric versus optimum power load training on components of physical fitness in young male soccer players. International journal of sports physiology and performance, 15(2), 222-230.

https://doi.org/10.1123/ijspp.2019-0039

Hager, R., Poulard, T., Nordez, A., Dorel, S., \& Guilhem, G. (2020). Influence of joint angle on muscle fascicle dynamics and rate of torque development during isometric explosive contractions. Journal of Applied Physiology, 129(3), 569-579. https://doi.org/10.1152/japplphysiol.00143.2019

Kolumbet, A.N., Natroshvili, S.G dan Chernovsky S.M (2018). Energy supply during cyclist muscular activity. Journal of Physical Education and Sport, 18(1), 98-102. https://doi.org/10.7752/jpes.2018.01012

Nugroho, S., Nasrulloh, A., Karyono, T. H., Dwihandaka, R., \& Pratama, K. W. (2021). Effect of intensity and interval levels of trapping circuit training on the physical condition of badminton players. Journal of Physical Education and Sport, 21(s3), 1981-1987. https://doi.org/10.7752/jpes.2021.s3252

Nasrulloh, A., Prasetyo, Y., Nugroho, S., Yuniana, R., Pratama, K. W., Mustapha, A., \& Idrus, S. Z. S. (2020). Tricet Method to Increase the Hypertrophy Muscle. Journal of Physics: Conference Series, 1529, 032006. https://doi.org/10.1088/1742-6596/1529/3/032006

Ehlert, A. (2020). The effects of strength and conditioning interventions on golf performance: A systematic review. Journal of Sports Sciences, 38(23), 2720-2731. https://doi.org/10.1080/02640414.2020.1796470

Rahman, M. H., \& Islam, M. S. (2020). Stretching and flexibility: A range of motion for games and sports. European Journal of Physical Education and Sport Science, 6(8).

Bolotin, A., \& Bakayev, V. (2018). Pedagogical practice for development of coordination potential of MMA fighters and estimation of its efficiency. Journal of Human Sport and Exercise, 13(1), 72-88.

https://doi.org/10.14198/jhse.2018.131.08

Hughes, G. (2019). Gender differences in intra-limb coordination during single limb landings on dominant and non-dominant legs. Journal of Human Sport and Exercise, 15(1), 1-9. https://doi.org/10.14198/jhse.2020.151.02

Le, T., Graham, J. D., King-Dowling, S., \& Cairney, J. (2020). Perceptions of Ability Mediate the Effect of Motor Coordination on Aerobic and Musculoskeletal Exercise Performance in Young Children at Risk for Developmental Coordination Disorder. Journal of Sport \& Exercise Psychology, 42(5), 407-416. https://doi.org/10.1123/jsep.2019-0155

Thomson, D. R., Rhoda, D. A., Tatem, A. J., \& Castro, M. C. (2020). Gridded population survey sampling: A systematic scoping review of the field and strategic research agenda. International Journal of Health Geographics, 19(1), 34. https://doi.org/10.1186/s12942-020-00230-4

Montalvo, S., \& Dorgo, S. (2020). The effect of different stretching protocols on vertical jump measures in college age gymnasts. The Journal of Sports Medicine and Physical Fitness, 59(12). https://doi.org/10.23736/S0022-4707.19.09561-6

Hidayat, R., Budi, D. R., Purnamasari, A. D., Febriani, A. R., \& Listiandi, A. D. (2020). Faktor Fisik Dominan Penentu 
Keterampilan Bermain Sepak Takraw. Jurnal MensSana, 5(1), 33. https://doi.org/10.24036/jm.v5i1.127

Ramadhan, A., \& Bulqini, A. (2018). Analisis Receive pada Pertandingan Final Sepak Takraw Pomda Jatim 2017. JSES : Journal of Sport and Exercise Science, 1(1), 13. https://doi.org/10.26740/jses.v1n1.p13-19

Wahyudi, W., Budiman, D., \& Saepudin, E. (2018). Penerapan Model Pembelajaran Kooperatif Tipe TGT dalam Pembelajaran Permainan Bola Besar Berorientasi Sepak Takraw untuk Meningkatkan Kerjasama dan Keterampilan Bermain. TEGAR: Journal of Teaching Physical Education in Elementary School, 1(2), 1. https://doi.org/10.17509/tegar.v1i2.11732

Van Biesen, D., Burns, J., Mactavish, J., Van de Vliet, P., \& Vanlandewijck, Y. (2021). Conceptual model of sportspecific classification for para-athletes with intellectual impairment. Journal of Sports Sciences, 39(sup1), 19-29. https://doi.org/10.1080/02640414.2021.1881280

Suprijono, A. (2015). Symbolic Meaning of Agate Stone as a Local Knowledge of Agate Fans Community for Learning Resource Development of Social Studies. Mediterranean Journal of Social Sciences.

https://doi.org/10.5901/mjss.2015.v6n3s1p527

Dimyati dan Mudjiono. (2012). Belajar Dan Pembelajaran. Jakarta : Rineka Cipta
Chen, S., Dai, H., Tang, J., \& Xiao, R. (2018). Physiological Profile of Sepak Takraw University Players. Topics In Education, Culture and Social Development, 63-66. https://doi.org/10.26480/icecsd.01.2018.63.66

Chen, S., \& Xiao, R. (2017). Physiological Profile of Filipino Sepak Takraw College Players. Asia Pacific Journal of Education, Arts and Sciences, 4(4), 69-74.

Casadio, J. R., Kilding, A. E., Cotter, J. D., \& Laursen, P. B. (2017). From Lab to Real World: Heat Acclimation Considerations for Elite Athletes. Sports Medicine, 47(8), 1467-1476. https://doi.org/10.1007/s40279-016-0668-9

Ohtani, K., \& Hisasaka, T. (2018). Beyond intelligence: A meta-analytic review of the relationship among metacognition, intelligence, and academic performance. Metacognition and Learning, 13(2), 179-212. https://doi.org/10.1007/s11409-018-9183-8

Kurniawan, A. (2017). The Correlation of Emotional Intelligence and Spiritual of Intelligence to Effectiveness Principals of Leadership. International Journal of Psychological and Brain Sciences, 2(1), 1. https://doi.org/10.11648/j.ijpbs.20170201.11

Huda Miftahul (2012). Model-model pengajaran dan pembelajaran. Yogyakarta: Pustaka Belajar 2012.

\title{
ВПЛИВ РІВНЯ ЗНАНЬ (IQ) І ФІЗИЧНИХ КОНДИЦІЙ (СИЛА, ГНУЧКІСТЬ І КООРДИНАЦІЯ) НА НАВИЧКИ НАВЧАННЯ ТЕХНІКИ УДАРУ В СЕПАК-ТАКРО
}

\author{
Юфріаніс $^{1 \mathrm{ABCE}}$, Раффлі Хенджиліто ${ }^{2 \mathrm{CDE}}$, Ернаван $^{3 \mathrm{CDE}}$, Сукірі ${ }^{3 \mathrm{CDE}}$, \\ Абдул Сукур ${ }^{3 \mathrm{CDE}}$, Діндін Абідін ${ }^{4 \mathrm{BDE}}$, Маніл Каракаукі ${ }^{5 \mathrm{BDE}}$, Сайед \\ Камарузаман Сайед Алі ${ }^{5 \mathrm{BDE}}$, Кукух Вахьюдін Пратама ${ }^{6 \mathrm{ACDE}}$ \\ ${ }^{1}$ університет Пахлаван Туанку Тамбусай \\ ${ }^{2}$ Університет Іслам Ріау \\ ${ }^{3}$ Університет Негері Джакарта \\ ${ }^{4}$ Університет ісламу 45 Бекасі \\ ${ }^{5}$ Університет Малая \\ ${ }^{6}$ Інститут передової науки, техніки та освіти
}

Авторський вклад: А - дизайн дослідження; В - збір даних; C - статаналіз; D - підготовка рукопису; Е - збір коштів

Реферат. Стаття: 9 с., 7 рис., 9 табл., 28 джерел.

Мета дослідження. Метою цього дослідження було виявити прямий вплив між рівнем знань (IQ) і фізичними кондиціями (сила, гнучкість і координація) на навички навчання техніки удару в сепак-такро.

Матеріали та методи. Метод, використаний в цьому дослідженні, був кількісним. Для аналізу результатів було проведено аналіз шляху ANOVA. Всього було прийнято 50 спортсменів сепак-такро зі столиці Джакарти. Ці спортсмени також були взяті в якості вибірки з генеральної сукупності. До вибірки увійшли спортсмени, які взяли участь в чемпіонатах області і країни.

Результати. На підставі дослідження було отримано: 1) рівень знань (IQ) безпосередньо впливає на навички навчання техніки удару в сепак-такро в розмірі 0,$982 ; 2)$ фізичні кондиції (сила, гнучкість і координація) безпосередньо впливають на навички навчання техніки удару в сепак такрав на 0,845 ; і 3) в цілому рівень знань (IQ) і фізичні кондиції (сила, гнучкість і координація) безпосередньо впливають на навички навчання техніки удару в сепактакро до 0,703.

Висновки. Таким чином, можна зробити висновок, що рівень знань (IQ) і фізичні кондиції (сила, гнучкість і координація) впливають на навички в навчанні техніки удару в сепак-такро у спортсменів столиці Джакарти.

Ключові слова: рівень знань (IQ), фізичний стан, техніка удару, сепак-такро. 


\section{Information about the authors:}

Jufrianis: jufrianis@universitaspahlawan.ac.id; https://orcid.org/0000-0002-5526-296X; Department of Physical Education, Health and Recreation; Universitas Pahlawan Tuanku Tambusai, Kampar-Riau, 28412, Indonesia.

Raffly Henjilito: rafflyhenjilito@edu.uir.ac.id; https://orcid.org/0000-0003-3804-8950; Department of Physical Education, Health and Recreation, Universitas Islam Riau, Pekanbaru-Riau, 28284, Indonesia.

Hernawan: hernawan@unj.ac.id; https://orcid.org/0000-0002-4257-5713; Department Sport Science, Universitas Negeri Jakarta, Jakarta Timur, 13220, Indonesia.

Sukiri: sukiri@unj.ac.id; https://orcid.org/0000-0003-3748-3889; Department Sport Science, Universitas Negeri Jakarta, Jakarta Timur, 13220, Indonesia.

Abdul Sukur: abdul-sukur@unj.ac.id; https://orcid.org/0000-0003-4008-9719; Department Sport Science, Universitas Negeri Jakarta, Jakarta Timur, 13220, Indonesia.

Dindin Abidin: dindinabidin70@gmail.com; https://orcid.org/0000-0001-7444-5916; Department of Physical Education, Health, and Recreation, Universitas Islam 45, Bekasi, West Java, 17113, Indonesia.

Manil Karakauki: manil@siswa.um.edu.my; https://orcid.org/0000-0003-4691-5727; Department of Physical and Health Education, Faculty of Education, University of Malaya, Kuala Lumpur, 50603, Federal Territory of Kuala Lumpur, Malaysia. Syed Kamaruzaman Syed Ali: syed@um.edu.my; https://orcid.org/0000-0002-4804-1237; Department of Physical and Health Education, Faculty of Education, University of Malaya, Kuala Lumpur, 50603, Federal Territory of Kuala Lumpur, Malaysia.

Kukuh Wahyudin Pratama: kukuh.pratama@iasee.org; https://orcid.org/0000-0003-4518-6358; Department of Sport Science Research and Development, Institute of Advanced Science, Engineering, and Education (IASEE), A-03A-05, Suria Jelutong, Jalan Bazar U8/99, Shah Alam, 40150, Selangor, Malaysia.

Cite this article as: Jufrianis, Henjilito, R., Hernawan, Sukiri, Sukur, A., Abidin, D., Karakauki, M., Syed Ali, S. K., \& Pratama, K. W. (2021). The Effect of Knowledge Level (IQ) and Physical Conditions (Power, Flexibility and Coordination) on Smash Technique Learning Skill in Sepak Takraw. Teoriâ ta Metodika Fizičnogo Vihovannâ, 21(3), 264-272. https://doi.org/10.17309/tmfv.2021.3.10

Received: 24.08.2021. Accepted: 07.09.2021. Published: 25.09.2021

This work is licensed under a Creative Commons Attribution 4.0 International License (http://creativecommons.org/licenses/by/4.0). 